\title{
El contrapunto en el álbum ilustrado infantil. Un análisis multimodal para su implementación en la asignatura llustración Infantil del Máster de Dibujo (Universidad de Granada)
}

\section{Resumen}

El álbum ilustrado infantil es una de las publicaciones para niños con mayor grado de experimentación literaria-plástica. La clave de estos libros radica en la relación entre la imagen y el texto, donde ambos medios colaboran entre sí para contar una historia común. Esta investigación se centra en los álbumes donde la relación multimodal es fundamentalmente de contrapunto, es decir, la imagen y el texto cuentan historias distintas, que incluso pueden llegar a contradecirse.

El objetivo de esta aportación es doble: en primer lugar, se profundiza en los recursos de interacción verbal-icónica que dan lugar al contrapunto en el álbum ilustrado; y, a posteriori, se diseña una actividad didáctica enfocada en la descodificación textual y visual de los álbumes analizados, con el objeto de implementarla como parte de la programación docente del Máster de Dibujo. El método empleado se basa en un estudio cualitativo de cinco álbumes contemporáneos publicados en español, tomando como punto de partida las categorías de contrapunto de Nikolajeva y Scott, y las clasificaciones de recursos metaficcionales descritos por Lewis y Zabala. Los resultados del análisis sirven de base para el diseño de la actividad, donde los estudiantes trabajarán los conceptos explicados previamente en el aula.

El análisis revela un claro predominio de los recursos denominados "estilo", "punto de vista" y "género" para crear el contrapunto fundamental en el álbum. La actividad didáctica muestra las dificultades de identificación del contrapunto en los álbumes no contradictorios. De esta manera, para mejorar la eficacia de la actividad, se proponen algunos ajustes, como son la ampliación del número de álbumes para reducir los grupos de trabajo, y la incorporación de álbumes de complemento para facilitar la comprensión de los conceptos por comparación.

\author{
$M^{\mathrm{a}}$ Carmen Hidalgo \\ Rodríguez \\ Doctora en Bellas Artes. \\ Profesora titular, Universidad de \\ Granada, Granada, España. \\ Correo electrónico: hidalgor@ugr.es \\ ๑ orcid.org/0000-0002-1676-2857 \\ Google Scholar
}

Recibido: diciembre 2 de 2020 Aprobado: junio 22 de 2021

\section{Palabras clave:}

álbum ilustrado, contrapunto, ilustración infantil, interacción imagen-texto, multimodal. 


\section{The Counterpoint in Picture Books for Children. A Multimodal Analysis for its Implementation in the Children Illustration Subject of the Master's Degree in Drawing (Universidad de Granada)}

\begin{abstract}
Picture books for children are publications with the highest degree of literary-plastic experimentation. The key to these books lies in the relationship between image and text, where both media collaborate with each other to tell a common story. This research focuses on picture books in which multimodal relationship is fundamentally one of counterpoints, that is, the image and the text tell different stories that may even contradict each other.

The objective of this contribution is twofold: first, it delves into the resources of verbal-iconic interaction that give rise to the counterpoint in the picture book and, a posteriori, a didactic activity focused on the textual and visual decoding of the picture books analyzed is designed, in order to implement it as part of the teaching programming of the Master's Degree in Drawing. The method used focuses on a qualitative study of five contemporary picture books published in Spanish, taking as a starting point the categories of counterpoint by Nikolajeva and Scott, and the classifications of the metafictional resources described by Lewis and Zabala. The results of the analysis serve as the basis for the design of the activity, where the students will work on the concepts previously explained in the classroom.
\end{abstract}

The analysis reveals a clear predominance of the devices called "style", "point of view" and "genre" to create the fundamental counterpoint in the picture book. The didactic activity shows the difficulties of identifying the counterpoint in the non-contradictory picture books. Thus, to improve the efficiency of the activity, some adjustments are proposed such as the expansion of the number of picture books to reduce the working groups, and the incorporation of additional picture books to facilitate the understanding of the concepts by comparison.
Palabras clave:

picture book, counterpoint, children's illustration, image-text interaction, multimodal. 


\section{Introducción}

En las primeras etapas del niño se encuentra una tipología específica de libro de ficción denominada normalmente álbum ilustrado o libro-álbum, "libros en los cuales tanto los recursos visuales como los verbales son esenciales para la comunicación completa" (Nikolajeva y Scott, 2000, p. 226). Es decir, las palabras y las imágenes colaboran para crear significados que no existirían si "leyésemos" estos dos medios de forma independiente. La narrativa sucede a partir de la interacción de varios lenguajes, en una polifonía compleja, que funciona en varios niveles de percepción (Van der Linden, 2015, p. 26).

Desde la aparición de los primeros álbumes ilustrados, que tuvo lugar en Inglaterra a finales del siglo XIX de la mano del editor Evans e ilustradores como Randolph Caldecott o Kate Greenaway (Barr, 1986; Whalley y Chester, 1988), estas publicaciones han evolucionado exponencialmente convirtiéndose en un producto más específico y complejo. Algunos autores "consideran a Caldecott como el padre del libro-álbum moderno, por haber sido el primero en entender que las imágenes podían servir de algo más que para ilustrar el texto de un libro" (Salisbury, 2005, p. 84). Sin embargo, el álbum ilustrado actual es una publicación mucho más sofisticada, debido precisamente a este carácter de interacción multimodal que encontramos en todas sus definiciones (Nodelman, 1990; Colomer, 1999, 2002; Nikolajeva y Scott, 2006; Salisbury y Styles, 2012), con un lenguaje visual complejo que demanda una decodificación del lector. Esta sería, por tanto, una de las claves fundamentales del álbum ilustrado y lo que lo diferencia de otras publicaciones para niños, donde las imágenes simplemente refuerzan o decoran el texto. En palabras de Teresa Colomer (2012): "para contar lo que allí sucede tenemos que recurrir tanto a lo que dicen las palabras, como a lo que 'dicen' las ilustraciones" (p. 19). 
Son diferentes los autores que han estudiado los códigos del álbum ilustrado desde distintas perspectivas. William Moebius (1986, citado en Salisbury, 2012) Ilamó la atención sobre los elementos del diseño del álbum analizando variables como el color, la perspectiva, el tamaño... Años más tarde, Gunther Kress y Theo van Leeuwen (1996), ponen de relieve la existencia de una gramática del diseño visual en su libro Reading Images: Grammar of Visual Design, desarrollando un profundo análisis semiótico sobre el álbum ilustrado.

Respecto a la relación multimodal de los álbumes, son varios los autores que describen al álbum como un icono que debe ser interpretado por el lector. Margaret Meek (1988) utiliza la palabra "interanimación" para definir la forma dinámica en que la imagen y el texto se relacionan en un álbum, creando nuevos significados de forma conjunta y dando lugar a diferentes interpretaciones.

Las relaciones multimodales en un álbum ilustrado son muy variadas, casi ilimitadas, y existen investigaciones que profundizan en este tipo de interacciones con el objeto de clasificarlas y hacerlas entendibles (Schwarcz, 1982; Golden, 1990; Nikolajeva y Scott, 2006). Entre estos estudios destaca la obra How Picturebooks Work de Nikolajeva y Scott (2006) donde hacen un análisis semántico exhaustivo de las relaciones multimodales en el álbum ilustrado infantil. Estas autoras clasifican al álbum ilustrado en dos grandes tipologías en función de la relación icónico-verbal: utilizan el término "complementario" para los álbumes ilustrados en los que las imágenes reflejan y amplían el texto escrito o en los que palabras e imágenes llenan los respectivos vacíos; y utilizan el término "contrapunto" cuando las palabras y las imágenes cuentan historias distintas y proporcionan información alternativa o se contradicen de algún modo, lo que se traduce en varias lecturas posibles. "Tan pronto como las palabras y las imágenes aporten información alternativa o contradictoria entre ellas de alguna manera, tenemos una variedad de lecturas e interpretaciones" (Nikolajeva y Scott, 2006, p. 17). Lo interesante 
del álbum de contrapunto (tal y como lo denominaremos a partir de ahora) es que el lector adopta una actitud activa debiendo interpretar la información dada, que destaca por su ambigüedad, generada a su vez por "las distintas líneas narrativas que se dificultan mutuamente" (Turrión-Penales, 2012, p. 62). En el álbum de complemento, sin embargo, la implicación del lector es menor.

Se parte de la hipótesis de que la complejidad del álbum ilustrado de contrapunto y las características del público al que va dirigido han dificultado su proliferación y consecuentemente su estudio profundo. Los métodos de análisis que se aplican ampliamente son aquellos que hacen referencia a la interacción entre texto e imagen tomando como punto de partida el texto. Este tipo de análisis debe ser ampliado en aquellos álbumes en los que el contrapunto surge tanto desde la imagen como desde el texto, ya que ambos medios cuentan una historia. Si bien el análisis del texto se rige por los análisis literarios perfectamente definidos y objetivos, el análisis de la ilustración es más subjetivo, pero cuenta con sus propias estrategias para narrar la historia de forma independiente y también en relación con el texto. En esta aportación se harán palpables las estrategias por las que la imagen narra historias por sí misma - y en combinación con el texto- a partir de cinco álbumes ilustrados, y los resultados se usarán como punto de partida para generar reflexión en el aula encaminada al aprendizaje y puesta en valor de este lenguaje visual.

Por tanto, el objetivo de este artículo es doble: por un lado, el estudio semiótico del álbum ilustrado de contrapunto respecto a las claves de interacción que se producen entre el texto y la imagen; y, por otro lado, diseñar e implementar una actividad didáctica — partiendo de la muestra de álbumes de contrapunto analizada - que contribuya al aprendizaje de este lenguaje por parte de los alumnos de Ilustración Infantil del Máster de Dibujo de la Universidad de Granada. 


\section{Metodología}

La metodología se estructura a partir de la fase de análisis de los álbumes, cuyos resultados serán reflejados en la actividad didáctica.

\section{El álbum de contrapunto y los modelos de análisis}

Para el análisis de la muestra se partirá de la clasificación básica aportada por Nikolajeva y Scott (2006) donde se distinguen dos tipos de álbumes de contrapunto: los que cuentan historias alternativas desde la imagen y el texto, y los que cuentan historias alternativas desde ambos medios, pero además contradictorias.

En la narración de dos historias alternativas al mismo tiempo, el papel de la imagen es clave, como puede verse en la colección Libros de Shirley de Burningham — por ejemplo, Time to Get Out of the Bath, Shirley (1999)—. El genio de Burningham muestra dos historias yuxtapuestas desde la imagen, la real, que se centra en la cotidianeidad y que procede directamente del texto, y el mundo imaginario de Shirley (sin reflejo en el texto).

Por otro lado, los álbumes de contrapunto con historias contradictorias suelen ser álbumes que utilizan la ironía para provocar la risa o el desconcierto debido al contraste que surge entre lo que se ve y lo que se lee. Dentro de esta tipología se encuadran álbumes ya clásicos como, por ejemplo, Lili Takes a Walk (Kitamura, 1991) y Rosie's Walk (Hutchins, 2015). En este último, el contrapunto fundamental se crea porque el texto describe el paseo rutinario de una gallina, sin contratiempos, sin embargo, en la imagen se ve a la gallina feliz perseguida por un zorro que intenta comérsela (y que no se menciona en el texto). 
Una vez que los álbumes de contrapunto están clasificados en estas dos tipologías, historias contradictorias, y no contradictorias, se le hacen las mismas preguntas respecto a las variables que se consideran en el análisis, lo cual permitirá comprobar las semejanzas y discrepancias entre ambos.

\section{Recursos de contrapunto en el álbum ilustrado según el modelo de Nikolajeva y Scott}

Como punto de partida para el análisis de la muestra se considerará el modelo aportado por Nikolajeva y Scott (2006), donde se distinguen ocho tipos de contrapunto en el álbum ilustrado: en el destinatario (atendiendo a si se distingue un doble destinatario niño-adulto en cuanto a la dificultad de la información contenida en el álbum), en estilo (distinguiendo un tono diferente en la concepción del texto y las imágenes, como por ejemplo, el texto puede ser irónico y las imágenes no), en género (distinguiendo dos tipos de género en función del grado de realismo, realidad y fantasía), por yuxtaposición (cuando se ofrecen dos historias paralelas desde la imagen), en punto de vista (cuando las palabras y las imágenes ofrecen distintas perspectivas o puntos de vista en cuanto a quién cuenta la historia), en los personajes (la presentación que se hace de los personajes en texto e imagen difiere y se contradice, o en la historia aparecen personajes que no son representados en ambos medios), de naturaleza metaficcional (cuando el texto expresa nociones que no pueden ser representadas en imágenes, como los cuadrados redondos) y, por último, contrapunto en espacio y tiempo (en este punto el texto y la imagen nunca pueden coincidir, ya que el texto es diegético — se comunica contando- y la imagen es mimética —se comunica mostrando—).

Aunque el contrapunto es un recurso que puede hallarse de manera puntual en un álbum, esta investigación se centra solo en álbumes ilustrados que 
mantienen el contrapunto a lo largo de la narración, donde el contrapunto está implícito en la concepción de la historia.

\section{El peso narrativo y el nivel de concreción de la historia}

En un álbum ilustrado, el mayor peso narrativo suele estar a cargo de la imagen, convirtiéndose en el medio fundamental para "leer" la historia. No obstante, Golden (1990), tras estudiar las relaciones entre texto e imagen en el álbum ilustrado, contempla otro tipo de posibilidades en cuanto al peso narrativo y las clasifica en cinco categorías, advirtiendo además que pueden aparecer combinadas dentro del mismo libro: 1) El texto y la imagen son simétricos, 2) El texto depende de la imagen para ser entendido, 3) La ilustración elabora y aclara el texto, 4) El texto es responsable de la narración principal y la ilustración es selectiva, y 5) La ilustración es la responsable de la narración principal y el texto es selectivo.

En una investigación posterior sobre las relaciones multimodales en el álbum (Hidalgo, 2015), donde se analizaron 18 álbumes contemporáneos de reconocido prestigio, se pudo comprobar cada una de estas interrelaciones, encontrando unas tipologías muy concretas que se definen a continuación:

- Álbum de complemento de ilustración selectiva. (10 álbumes). Se trata de álbumes donde el texto y la imagen cuentan la misma historia y donde cada medio aporta información complementaria, y además el ilustrador selecciona parte de la información que aporta el texto para elaborar la ilustración.

- Álbum de complemento de concreción. (3 álbumes). Texto e imagen cuentan la misma historia, aportando información complementaria, pero es la imagen la que concreta la historia. De manera que el texto por sí mismo no tendría un significado completo. 
- Álbumes de complemento de simetría. (2 álbumes). El texto y la imagen ofrecen la misma información. Es el grado mínimo de complemento entre texto e imagen.

- Álbumes de complemento simbólico. (1 álbum). La imagen no ilustra las acciones descritas en el texto, sino que es muy selectiva escogiendo personajes o elementos concretos y los muestra de forma aislada principalmente. Es muy poco usual en álbumes infantiles.

- Álbumes de contrapunto (de concreción). (2 álbumes). Texto e imagen cuentan historias distintas, y es la imagen la responsable de concretar la historia.

Tras este estudio se concluyó que, en los álbumes donde la relación multimodal es de complemento, el peso narrativo puede recaer en la imagen, en el texto, o repartirse entre ambos medios. Sin embargo, en los álbumes denominados de contrapunto, aunque en ese momento solo se encontraron dos álbumes, sí que estaba clara la condición de la imagen como elemento fundamental en la narración principal, puesto que las ilustraciones eran responsables de concretar la historia en ambos álbumes. No obstante, esto no tiene por qué ser siempre así en los álbumes de contrapunto; el peso narrativo puede estar repartido en ambos medios desde que el texto y la imagen pueden contribuir del mismo modo en la concreción de la historia.

Al mismo tiempo, la concreción de la historia puede estar relacionada con el final de la misma. Normalmente, los álbumes ilustrados contienen historias cerradas donde se da solución al problema creado. Pero se pueden encontrar historias sin cerrar, abiertas, y que pueden dar lugar a distintas interpretaciones, sobre todo tratándose de álbumes de contrapunto. 


\section{Recursos metaficcionales}

En los álbumes infantiles contemporáneos es habitual el uso de recursos metaficcionales para jugar entre lo real y lo imaginario, rompiendo así las estructuras narrativas clásicas y haciendo surgir la figura del "lector implícito", que tendrá que interactuar con la historia para extraer sus propias interpretaciones. "En la crítica parece haber un acuerdo general en definir la metaficción como un tipo de ficción que llama la atención sobre su propia construcción y por tanto sobre su condición de artefacto" (SilvaDíaz, 2005, p. 59).

En la mayoría de las clasificaciones sobre técnicas o rasgos metaficcionales que se pueden encontrar sobre publicaciones infantiles (Moss, 1990; McCallum, 1999; Lewis, 2001), se contemplan las narraciones alternativas (que pueden ser contradictorias o no) y, consecuentemente, distintos puntos de vista que provienen de la narración o del narrador. Aunque estas variables se centran fundamentalmente en el texto, se pueden aplicar también a la imagen. Contar varias historias al mismo tiempo es una característica intrínseca a la definición de álbum de contrapunto, por tanto, estará presente en cada libro de la muestra. No obstante, en el análisis se valorará la especial relevancia de este recurso para potenciar el contrapunto a lo largo del cuento e incluso en momentos concretos.

Igualmente interesantes son otros recursos más específicos que contribuyen al contrapunto, como los apuntados por Lewis (2001) denominados "Indeterminación" (situaciones que quedan sin resolverse y se mantienen turbias), y "Ruptura de la frontera narrativa" (consistente en la transgresión de barreras; por ejemplo, cuando el personaje cambia de nivel dentro de la narración o el autor se dirige directamente al lector), respectivamente. 
También, se considerarán los posibles juegos literarios que algunos autores denominan "La construcción lingüística de los textos" (McCallum, 1999) o "El juego con las palabras" (Moss, 1990), donde destaca, por ejemplo, el juego de palabras tematizado o las variaciones tipográficas que Ilaman la atención acerca de la condición material de los textos.

Otro recurso importante es el uso de metáforas visuales, vinculadas o no al texto. Moya-Guijarro (2016) demuestra que "la utilización de metáforas semióticas facilita la comprensión del mensaje al joven lector de cuentos álbum, dado que a través de ellas se representan fenómenos y estados de carácter abstracto de una forma más concreta y tangible" (p. 34) (utiliza el término "metáfora semiótica" para referirse a la metáfora aplicada al campo visual).

La ironía es otro de los recursos metaficcionales presentes en el álbum posmoderno. "Consiste en proponer una idea para que se entienda su contraria, produciendo un efecto hilarante" (Cao, 1998, p. 57). Cuando el lector descodifica un mensaje transmitido con ironía, obtiene un efecto placentero, empatizando con el productor del mensaje. Kümmerling-Meibauer (1999), respecto a la ironía dentro del álbum ilustrado, afirma que "la ironía en el álbum ilustrado puede producirse mediante la contradicción en el texto, mediante la contradicción en la imagen, o mediante la contradicción entre imagen y texto" (p. 162). Esta última posibilidad puede verse claramente reflejada en los álbumes de contrapunto contradictorios que Cecilia Bajour (2017) explica de la siguiente manera: "En los libros-álbum donde el juego irónico predomina, la distancia suele plantearse entre lo que dice y calla el texto escrito y lo que la imagen muestra u oculta" (p. 55).

Para la localización de diferentes usos de la ironía se tendrán en cuenta también las diferentes posibilidades apuntadas por Zabala (2005, p. 21): 
- La ironía literaria, que se desarrolla normalmente a partir de los juegos de palabras (nombrada más arriba por otros autores como "juegos literarios").

- La ironía icónica, que se produce a partir de mostrar una imagen o una yuxtaposición de imágenes para dar a entender un mensaje contradictorio.

- En la interacción de ambos lenguajes se produce el contrapunto irónico, del que hablaba Bajour (2017, p. 55).

- En función de la trama de la historia, si la ironía está presente a lo largo de la narración, se denomina ironía narrativa. Y dentro de esta se reconocen dos categorías: la ironía situacional (se produce una paradoja para un personaje en determinada situación) y la ironía dramática (cuando el receptor de la obra tiene más información que los propios personajes de la historia).

\section{Campo de actuación y método de análisis}

Respecto a la prospección de los libros que forman parte de la muestra, se valoraron álbumes ilustrados infantiles actuales publicados en español y que cumplieran las premisas de álbum de contrapunto en sus dos modalidades, con historias contradictorias y no contradictorias. En este sentido, se revisaron las editoriales especializadas en álbum infantil, considerando las publicaciones consolidadas en el mercado con premios o reediciones, o bien creados por autores de reconocido prestigio. El resultado de esta prospección dio lugar a la selección de cinco álbumes: Una casa para el abuelo (Toro y Ferrer, 2007), La familia C (Bruno y Cabassa, 2010), ¡No! (Altés, 2007), ¿Todavía nada? (Voltz, 2003) y El gato de Matilda (Gravett, 2014).

Para llevar a cabo el análisis de los álbumes se diseñó una base de datos con todas las variables a estudiar, lo que facilitaría a posteriori la extracción de resultados tanto cuantitativos como cualitativos. Estas variables se dividen en tres tipos: 
- Variables técnicas para catalogar el libro y que justifican su selección.

- Recursos de contrapunto en la relación texto-imagen descritos por Nikolajeva y Scott (2006): destinatario, estilo, género, yuxtaposición, punto de vista y personajes. Se excluye el "recurso de naturaleza metaficcional" (que se estudiará de forma más específica) y "espacio y tiempo" (por ser muy genérico y encontrarse implícito en otros recursos).

- Otros recursos que pueden contribuir al contrapunto multimodal: peso narrativo y concreción de la historia, el final de la narración, y recursos metaficcionales específicos.

\section{Diseño de la actividad didáctica}

En referencia a la implementación en el aula, se diseñó una actividad didáctica conducente al análisis, por parte de los estudiantes, de las relaciones entre el texto y la imagen de los cinco álbumes de la muestra. Esta actividad fue puesta en práctica durante el mes de octubre de 2020 como parte de la asignatura Ilustración Infantil I del Máster de Dibujo de la Universidad de Granada, compuesta por 30 estudiantes. Esta práctica corta se propone tras la exposición teórica de las diferentes posibilidades de relación multimodal en el álbum ilustrado, tanto de relaciones de complemento como de contrapunto. La lección en su conjunto, teoría y práctica, tiene una duración de dos horas y media, dedicando una hora y media a la teoría, y una hora a la práctica. La realización de la práctica se lleva a cabo en grupos de 6 alumnos, y se divide en dos fases: en la primera fase se reparten los álbumes de la muestra entre los 5 grupos creados, cada grupo responde a las cuestiones planteadas en el material de trabajo suministrado (que sintetiza el método de análisis explicado en clase con anterioridad) y en función del álbum proporcionado, es importante que los resultados sean consensuados por todos los miembros del grupo. En una segunda fase, cada uno de los grupos comparte con el aula los resultados de su análisis, generando un debate a partir de preguntas del 
docente conducentes a la comparación de los distintos álbumes. El material de trabajo suministrado a cada uno de los grupos para el análisis del álbum es el siguiente:

a. Decidir si el álbum suministrado se estructura bajo una relación multimodal de complemento o de contrapunto, y justificarlo.

b. En función de la clasificación anterior, seleccionar y justificar la tipología a la que pertenece:

- Álbum de complemento: de ilustración selectiva (acciones o complementos); de concreción; de simetría; simbólico.

- Álbum de contrapunto. Decidir previamente si tiene contradicción o no. A continuación, analizar qué tipo de recursos de contrapunto utiliza de entre los siguientes: estilo; género; yuxtaposición; punto de vista; y personajes (se simplifica en los 5 recursos que se consideran fundamentales).

c. Por último, se pide al alumno que valore qué medio (imagen y texto) es más concreto o ambiguo.

Los alumnos no serían informados previamente de que los 5 álbumes involucrados en la práctica destacan por el uso de recursos de contrapunto, con el objeto de que se replanteen todos los conceptos explicados anteriormente, tanto los de complemento como los de contrapunto.

\section{Resultados del análisis y de la actividad didáctica llevada a cabo}

Los resultados extraídos se dividen en dos grupos, denominados "variables básicas de contrapunto" y "otras variables", respectivamente. El conjunto de los resultados será mostrado de forma sintética en una tabla y a continuación se destacará lo más relevante. Por último, se mostrarán los resultados de la actividad didáctica. 


\section{Variables básicas de contrapunto}

En la siguiente tabla se muestran los principales resultados respecto a las variables de contrapunto presentes en cada uno de los álbumes que forman parte de la muestra analizada.

Tabla 1. Resultados sobre las variables básicas de contrapunto en cada uno de los álbumes

\begin{tabular}{|c|c|c|c|c|c|c|}
\hline \multicolumn{2}{|c|}{$\begin{array}{l}\text { Álbumes } \\
\text { /Variables de contrapunto }\end{array}$} & $\begin{array}{l}\text { Una casa para el } \\
\text { abuelo (H.N.C.) }\end{array}$ & $\begin{array}{l}\text { La familia C } \\
\text { (H.N.C.) }\end{array}$ & $\begin{array}{l}\text { ¡No! } \\
\text { (H.C.) }\end{array}$ & $\begin{array}{l}\text { ¿Todavía nada? } \\
\text { (H.N.C.) }\end{array}$ & $\begin{array}{l}\text { El gato de } \\
\text { Matilda } \\
\text { (H.C.) }\end{array}$ \\
\hline \multicolumn{2}{|l|}{ Destinatario } & Sí & No & No & Sí & No \\
\hline \multirow[t]{2}{*}{ Estilo } & Texto & $\begin{array}{l}\text { Objetivo } \\
\text { (Realista y } \\
\text { sintético) }\end{array}$ & $\begin{array}{l}\text { Objetivo } \\
\text { (Realista y } \\
\text { cotidianeidad) }\end{array}$ & Ingenuo & $\begin{array}{l}\text { Ingenuo } \\
\text { (Romántico) }\end{array}$ & Ingenuo \\
\hline & Imagen & Romántica & Romántica & Realista & Realista & Realista \\
\hline \multirow{2}{*}{ Género } & Texto & Realista & Realista & \multirow{2}{*}{$\begin{array}{l}\text { No } \\
\text { (Realista) }\end{array}$} & \multirow{2}{*}{$\begin{array}{l}\text { No } \\
\text { (Realista) }\end{array}$} & \multirow{2}{*}{$\begin{array}{l}\text { No } \\
\text { (Realista) }\end{array}$} \\
\hline & Imagen & Fantástica & Fantástica & & & \\
\hline \multirow{2}{*}{ Yuxtaposición } & Texto & \multirow{2}{*}{ No } & \multirow{2}{*}{ No } & \multirow{2}{*}{ No } & No & Sí \\
\hline & Imagen & & & & Sí & No \\
\hline \multirow{2}{*}{$\begin{array}{l}\text { Punto de } \\
\text { vista } \\
\text { (P.V.) }\end{array}$} & Texto & Nieta mayor & \multirow{2}{*}{ No } & Perro & $\begin{array}{l}2 \text { P.V.: Luis } \\
\text { (narrador); y } \\
\text { narrador subjetivo. }\end{array}$ & $\begin{array}{l}2 \text { P.V.: Matilda } \\
\text { antes y después } \\
\text { del juego. }\end{array}$ \\
\hline & Imagen & Abuela y abuelo & & $\begin{array}{l}\text { La familia } \\
\text { (la realidad) }\end{array}$ & $\begin{array}{l}3 \text { P.V.: Luis; el } \\
\text { pájaro; y } \\
\text { el espectador. }\end{array}$ & El gato \\
\hline \multirow{2}{*}{ Personajes } & Texto & $\begin{array}{l}\text { El abuelo ausente } \\
\text { hasta mitad del } \\
\text { cuento }\end{array}$ & \multirow{2}{*}{ No } & $\begin{array}{l}\text { Perro y } \\
\text { familia }\end{array}$ & \multirow{2}{*}{ No } & \multirow{2}{*}{ No } \\
\hline & Imagen & $\begin{array}{l}\text { El abuelo está } \\
\text { presente siempre }\end{array}$ & & $\begin{array}{l}\text { Perro } \\
\text { (familia una } \\
\text { sola vez) }\end{array}$ & & \\
\hline
\end{tabular}

Nota. H.N.C.: historias no contradictorias. H.C.: historias contradictorias. Fuente: elaboración propia. 


\section{Destinatario}

Dos de los cinco álbumes analizados se consideran con "doble destinatario" por la complejidad en la construcción de la historia. En uno de los casos, Una casa para el abuelo, la complejidad viene determinada por la función de la imagen, que concreta la historia a nivel metaficcional bajo el aspecto denominado "Indeterminación" (Lewis, 2001), dando lugar a distintas interpretaciones a lo largo de la narración y al final de la historia. En el segundo caso, ¿Todavía nada?, la complejidad se centra en los distintos puntos de vista que ofrece la narración y que se explica más adelante.

\section{Estilo y género}

Las variables de estilo y género se encuentran muy relacionadas entre sí, según se deduce de los datos presentados en la Tabla 1. Tres de los álbumes responden a la dicotomía ingenuo (texto)-realista (imagen) en cuanto al estilo, y ninguno de estos tres álbumes presenta contrapunto en el género, siendo ambos medios narrativos realistas.

La ingenuidad encontrada en el texto, respecto al estilo, se refleja en los protagonistas de estos álbumes. Dos de estos libros, ¡No! y ¿Todavía nada?, están protagonizados por personajes que se mantienen ajenos a la realidad durante toda la narración. El máximo grado de ingenuidad se puede ver en ¡No!, donde Rufus, el perro protagonista, se muestra encantado por lo que cree que son muestras de cariño por parte de sus dueños. En este caso, la ingenuidad del perro transmitida desde el texto, y los resultados realistas y desastrosos narrados visualmente, contribuyen al contrapunto irónico que provoca perplejidad e hilaridad en el lector. Por ejemplo, el texto dice "Pruebo su comida antes que ellos para asegurarme de que no está mala", mientras la imagen muestra cómo el perro coge un muslo de pollo directamente del 
plato ya servido en la mesa y una voz fuera de campo grita "¡NOO!" (Figura 1). Rufus cree que se Ilama No, así que se siente premiado y querido cada vez que le niegan algo.

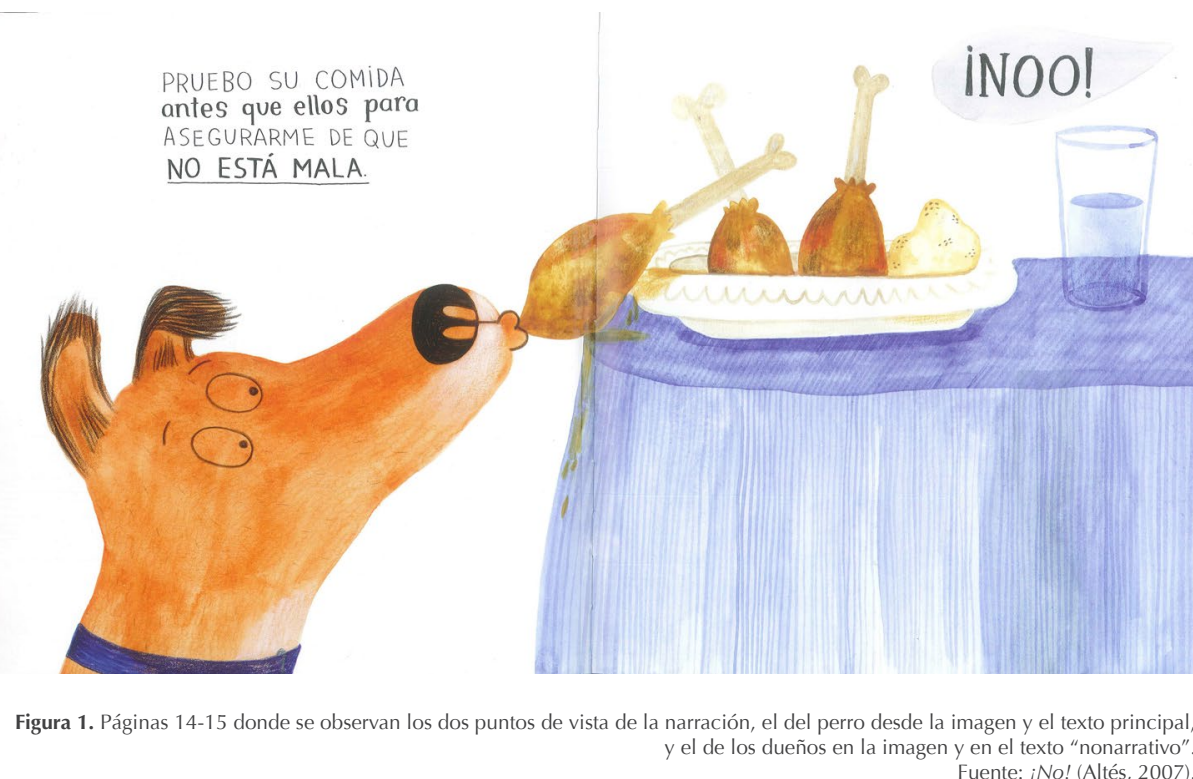

En El gato de Matilda, la protagonista es ingenua no por el desconocimiento de la realidad, sino por su empeño en que su gato juegue con ella, cuando la imagen muestra claramente que el gato no está dispuesto (Figura 3). Al igual que el álbum iNo!, se trata de una historia contradictoria, marcada también por diferentes usos de la ironía pero que en este caso no resultan tan cómicos. 
Los otros dos álbumes, Una casa para el abuelo y La familia C, responden al binomio objetivo (texto)-romántico (imagen) en cuanto al estilo, y ambos coinciden con el binomio realista (texto)-fantástico (imagen) en cuanto al género. En este caso, los dos son álbumes de contrapunto de historias no contradictorias, que cuentan con un protagonista de carácter romántico. Curiosamente, ambos binomios de contrapunto juegan en paralelo de manera que el texto realista refuerza el texto objetivo, y la imagen romántica contribuye a la fantasía de la misma (Figura 2). Las dos historias siguen los mismos recursos para construir la narración y el contrapunto: es la imagen la que concreta la historia.

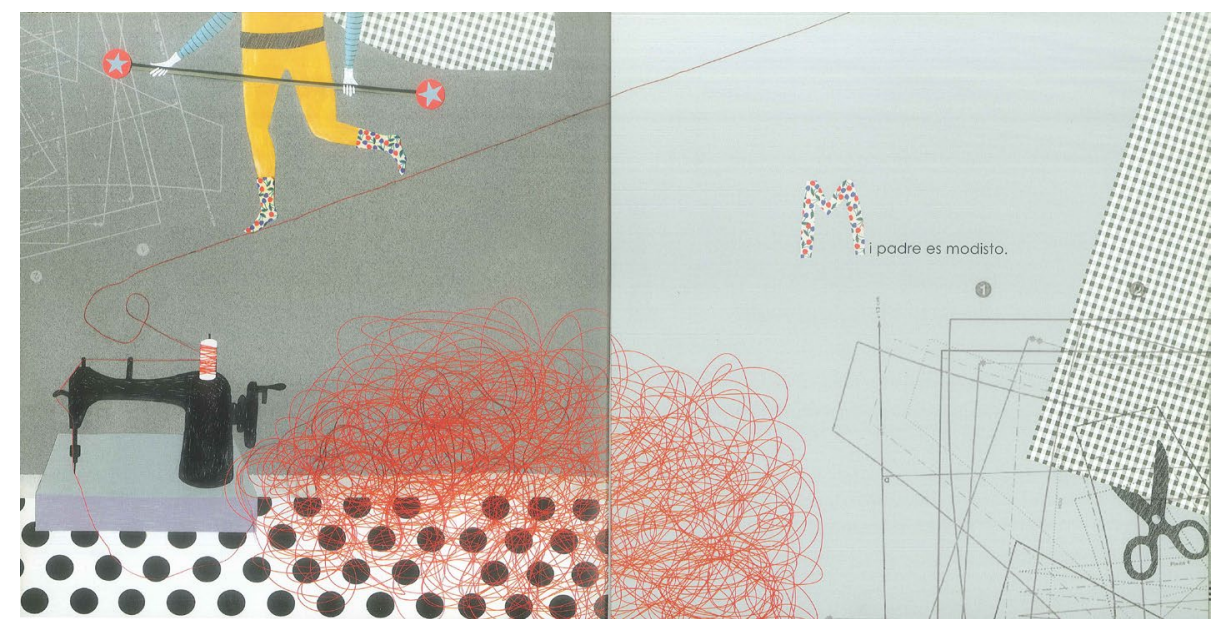

Figura 2. Páginas 14-15 donde el texto es realista y objetivo, y la imagen es romántica y fantástica. Fuente: La familia C (Bruno y Cabassa, 2010). 


\section{Punto de vista}

Cuatro de los cinco álbumes analizados presentan contrapunto respecto al punto de vista que ofrece la imagen por un lado y el texto por otro. Se observan diferentes recursos para crear este contrapunto:

- Mediante el uso de varios narradores, uno para el texto y otro para la imagen. Esto es lo que ocurre en Una casa para el abuelo, mientras en el texto es la nieta la que cuenta la historia (en $1^{\mathrm{a}}$ persona del plural) destacando al abuelo como protagonista, en la imagen la narradora principal es la abuela, que se convierte en protagonista junto al abuelo tomando el control de la historia. El punto de vista de la nieta es objetivo (en el texto), mientras que el punto de vista de la abuela es romántico (texto e imagen).

- Ofreciendo información contradictoria entre la imagen y el texto. En este sentido, hay una relación directa con los álbumes de contrapunto contradictorios. En ¡No!, el texto principal es la voz narrativa en primera persona del perro, el protagonista, que ofrece un punto de vista muy positivo sobre él mismo, que contrasta en extremo con lo que se ve en la imagen, que sería el punto de vista de la familia. Una fórmula parecida se encuentra en El gato de Matilda (Figura 3), donde el texto principal, sin tachar, (un narrador externo omnisciente) se centra en la actitud de Matilda (positiva y romántica); mientras la imagen se centra fundamentalmente en las acciones del gato (negativas y nada alentadoras). En este álbum se juega además con dos momentos distintos de la ilustración que apoyan este P.V.: en la página recto se representa a Matilda con sus propuestas, y en la página verso al gato negándose a participar. 


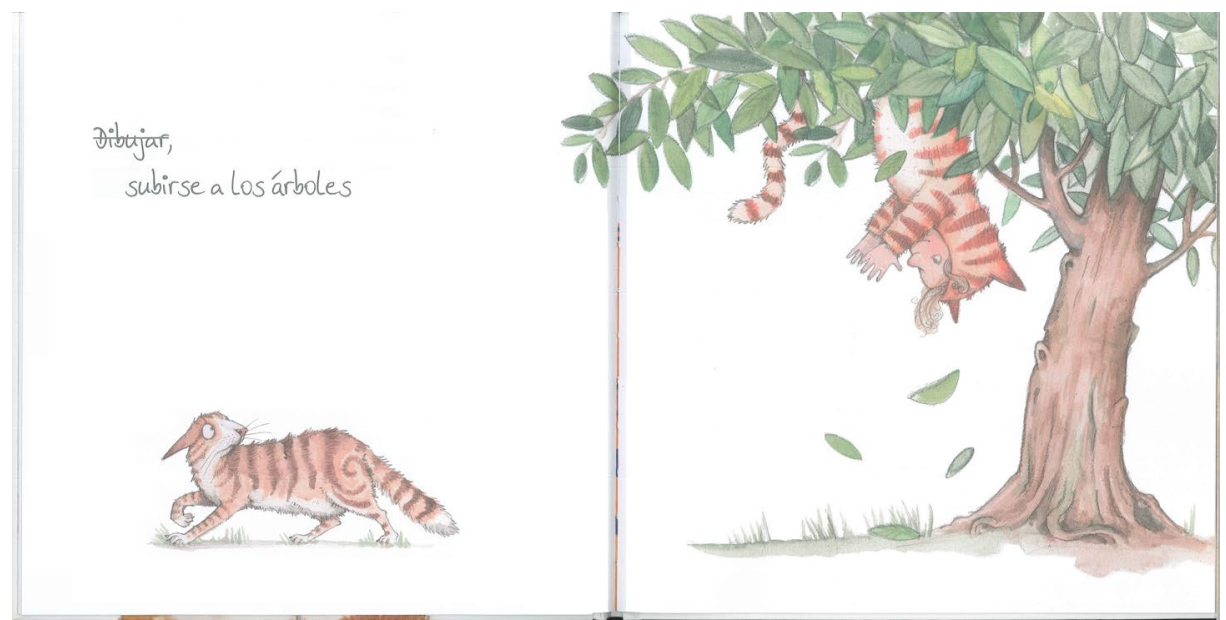

Figura 3. Páginas 20-21 donde se observan los dos puntos de vista del álbum, el P.V. de Matilda en el texto normal (que previamente se ha introducido con "Al gato de Matilda le gusta"); y el P.V. del gato, reflejado en la imagen fundamentalmente. Fuente: El gato de Matilda (Gravett, 2014).

- La imagen aporta dos puntos de vista distintos, y uno de ellos no tiene su reflejo en el texto. En ¿Todavía nada?, un narrador externo (en $3^{a}$ persona) cuenta las acciones de Luis, el protagonista, y de un pájaro, un personaje secundario. A priori se trata de un narrador omnisciente, sin embargo, este narrador aporta también un punto de vista subjetivo dirigiéndose al lector, y rompiendo así la frontera narrativa (Figura 7). En la imagen se encuentra este mismo punto de vista donde Luis es el protagonista, pero, además, el punto de vista del espectador, que tiene acceso a información que los personajes no pueden ver (cómo va creciendo la planta debajo de la tierra) (Figura 4). 


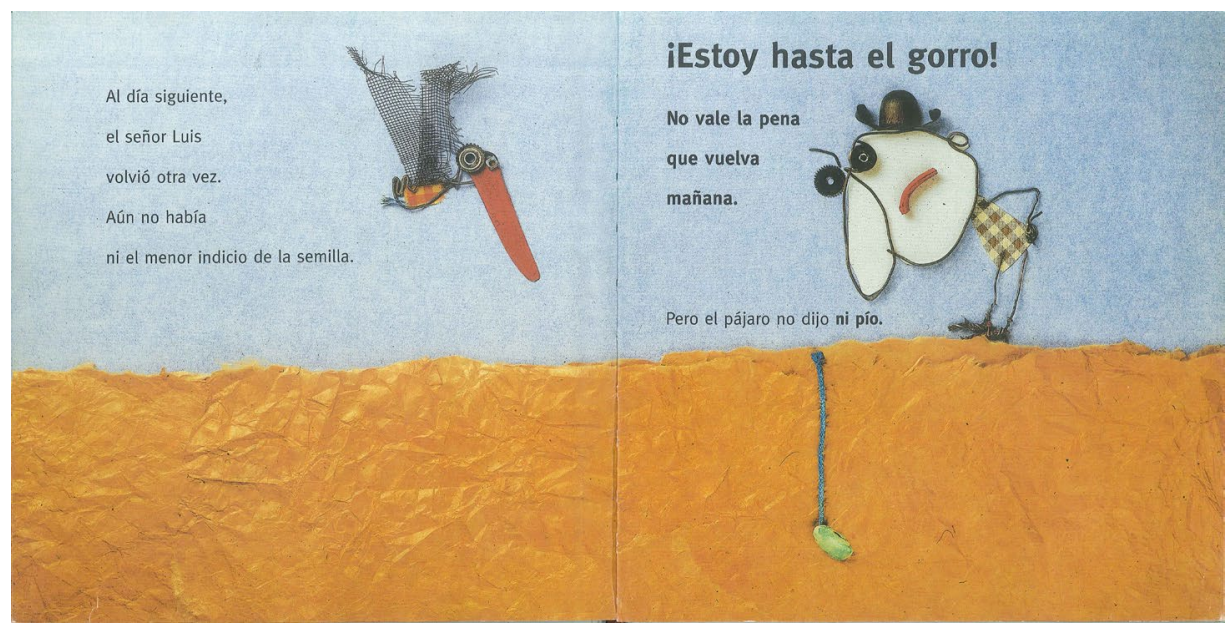

Figura 4. Doble página 24-25 que ilustra los dos puntos de vista fundamentales del álbum: el P.V. del protagonista (Luis), que en este caso coincide con el P.V. del pájaro; y el P.V. del espectador. Fuente: ¿Todavía nada? (Voltz, 2003).

\section{Personaje}

No se encuentra contrapunto respecto a los personajes en ninguno de los álbumes. No obstante, hay que destacar dos álbumes donde se produce este contrapunto de forma parcial. En Una casa para el abuelo, aunque el abuelo es el protagonista de la historia en el texto, no se le nombra explícitamente hasta la mitad del libro, mientras que en la imagen aparece desde el principio. Es un recurso interesante porque se mantiene el misterio del objetivo del viaje que ha iniciado la familia y la identificación del abuelo, pero aportando pistas desde la imagen. En iNo!, el contrapunto en cuanto a personajes es más sutil; mientras la voz narrativa del perro menciona constantemente a la familia, esta no aparece en la imagen hasta el final del cuento (Figura 5). La intención es mantener la tensión en torno a lo que el perro cree y la realidad. Al no ver 
en escena a la persona que grita la palabra “¡No!" como texto intraicónico, no tiene tanta fuerza como negación, y siembra la duda sobre su significado, alimentando así la creencia del perro de que sus actos no son malos.
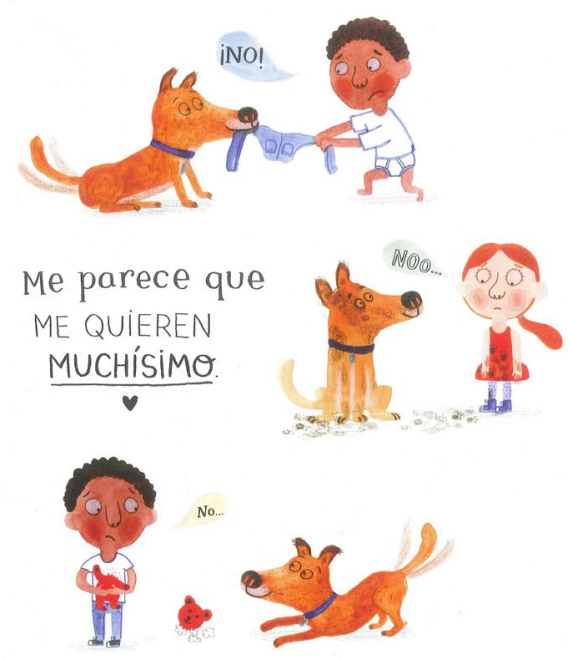
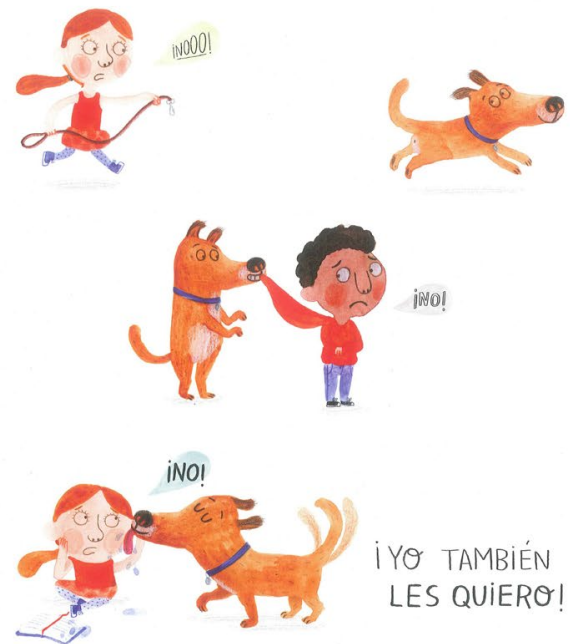


\section{Yuxtaposición}

En ninguno de los álbumes seleccionados existe realmente contrapunto en cuanto a la yuxtaposición, puesto que las historias que se ofrecen desde la imagen son únicas. Sin embargo, el juego que se hace en la ilustración con dos puntos de vista distintos en ¿Todavía nada?, ofrece de alguna manera al espectador dos historias distintas: la que vive Luis principalmente (y el pájaro en segunda persona), y la que vive el espectador, más completa y que da respuesta a las dudas del protagonista. También, cabría mencionar aquí el juego que se hace en El gato de Matilda desde el texto, mostrando dos momentos distintos de la historia: los deseos de Matilda (texto normal); y la realidad, en un momento posterior a la acción que se refleja en la imagen (en la página siguiente y tachado) (Figura 3).

\section{Otras variables}

En este apartado se estudian otras variables que pueden ser decisivas para aportar o potenciar el contrapunto de la historia. En la Tabla 2 se muestran los resultados de esta segunda fase de análisis por cada unos de los álbumes de la muestra. 
Tabla 2. Resultados sobre otras variables de contrapunto estudiadas en los álbumes de la muestra

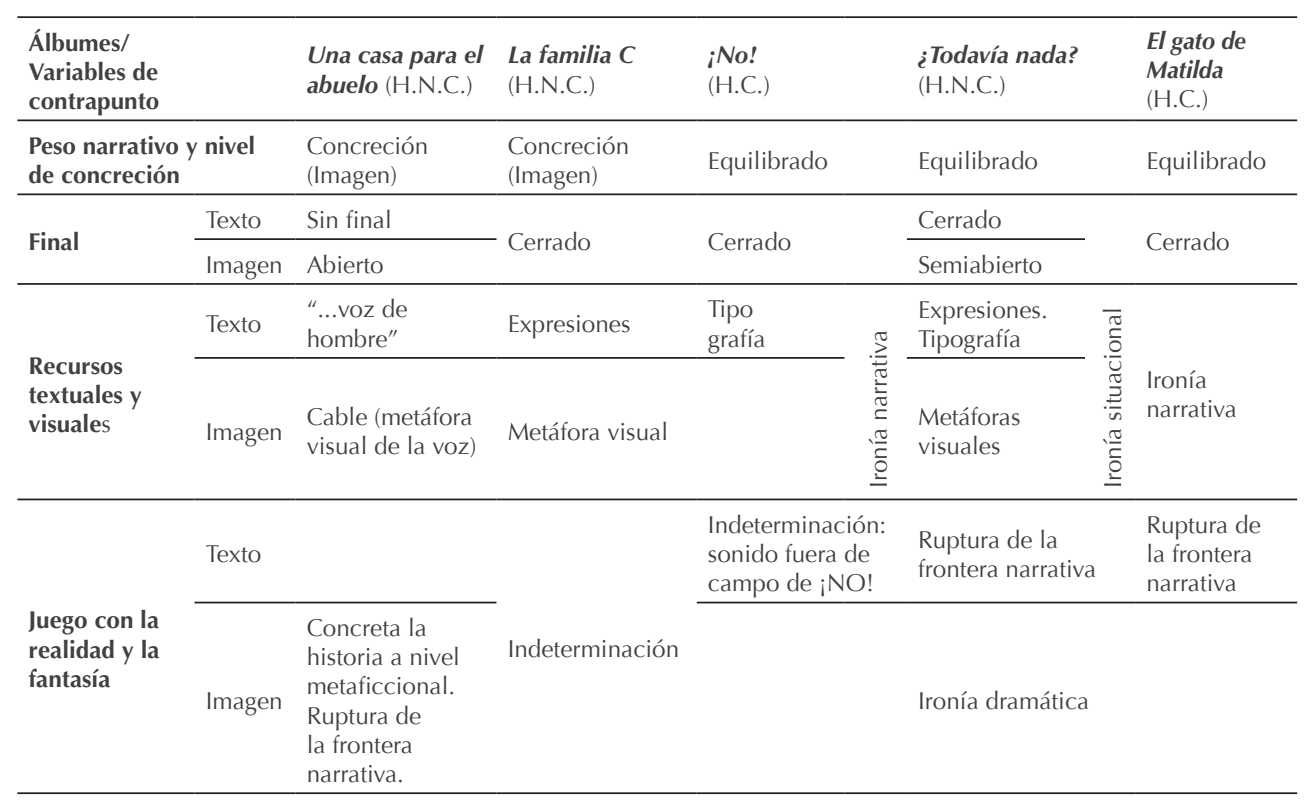

Nota. H.N.C.: historias no contradictorias. H.C.: historias contradictorias.

Fuente: elaboración propia.

\section{Concreción de la historia y peso narrativo}

Se encuentra una relación directa entre la concreción de la historia y el peso narrativo. Tres de los álbumes de la muestra tienen un nivel de concreción de la historia y peso narrativo "equilibrado" entre ambos medios. Sin embargo, obedece a justificaciones distintas. En los dos álbumes de contrapunto con historias contradictorias (¡No! y El gato de Matilda), la contradicción surge del aporte de información opuesta que se da desde la imagen y el texto, producto de la ironía narrativa. Sin embargo, en el tercer álbum, ¿Todavía 
nada?, con historias no contradictorias, el equilibrio icónico-verbal se debe al complejo entramado de la historia que surge de ambos medios y directamente relacionado con los diversos puntos de vista que se ofrecen, como se ha visto anteriormente.

Los otros dos álbumes responden a álbumes donde la imagen es la responsable de concretar la historia, por tanto, el mayor peso narrativo recae en la imagen (Figura 6).

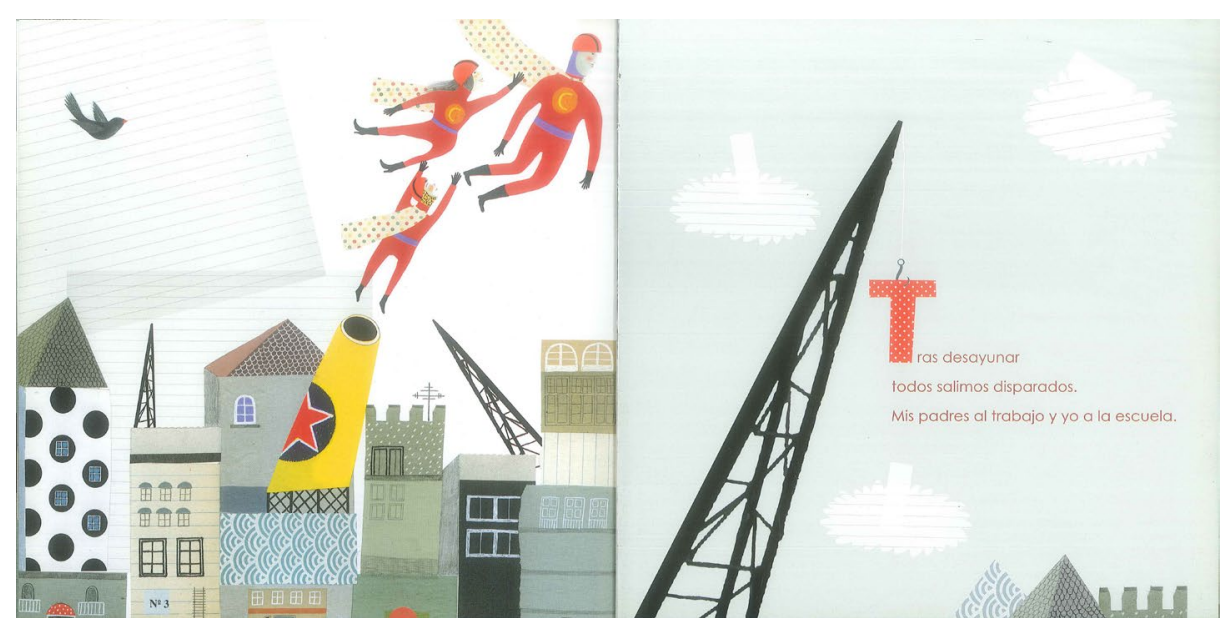

Figura 6. Álbum donde la imagen concreta la historia y doble página 12-13 donde la ilustración interpreta la expresión verbal "salimos disparados" de forma literal.

\section{El final del cuento}

Los álbumes de contrapunto contradictorios de la muestra tienen finales cerrados, tanto desde el texto como desde la imagen. En los no contradictorios 
se encuentran finales cerrados y abiertos (predominando los abiertos, 2 frente a 1). En estos casos, cuando el final es abierto, es la imagen la responsable de cerrar la historia, aportando ambigüedad.

\section{Recursos textuales y visuales}

El uso de la ironía se encuentra de forma explícita a lo largo de la narración en los dos álbumes de contrapunto con historias contradictorias (ironía narrativa). Pero la ironía también se encuentra presente en el álbum ¿Todavía nada? de forma puntual, "ironía situacional" (Zabala, 2005, p. 26), cuando Luis, después de haber cuidado la planta durante tanto tiempo, se queda sin la flor por perder la paciencia en el último momento, en el que el pájaro supuestamente pasa de forma casual llevándose la flor consigo (Figura 7).

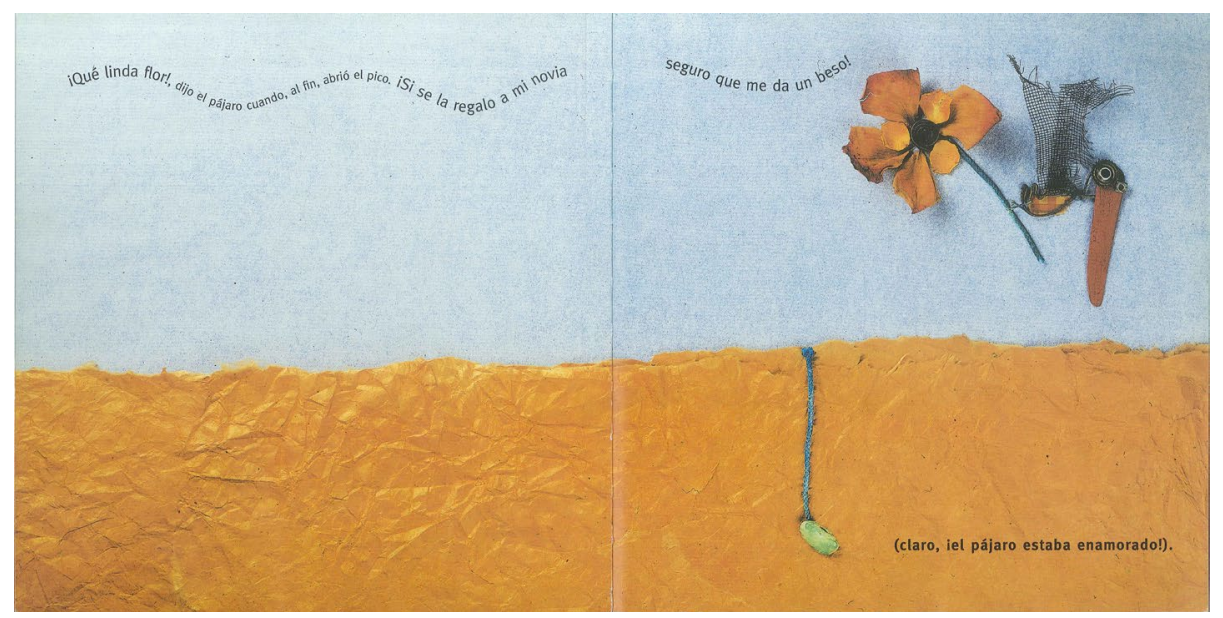

Figura 7. Páginas 32-33, donde tiene lugar una ironía situacional cuando el pájaro se lleva la flor que Luis ha estado cuidando. Fuente: ¿Todavía nada? (Voltz, 2003). 
En tres de los álbumes analizados se encuentran diferentes juegos metafóricos entre el texto y la imagen. En Una casa para el abuelo, cuando el texto dice "La abuela nos cuenta historias por la noche", la imagen muestra a la familia reunida en la casa y un cable que sale de la Luna traspasando la doble página y conectando con las siguientes hasta llegar a la boca del abuelo (Figura 8), donde el texto dice "Cuando llega a la historia de la construcción del barco siempre le sale voz de hombre". El cable, cuya función principal es destacar y conectar a los protagonistas de la imagen (Moya-Guijarro, 2017, p. 451), simboliza la voz del abuelo, que se muestra en su tumba jugando con un barquito de papel. En la Familia C se observa un juego parecido cuando el texto dice "Tras desayunar todos salimos disparados. Mis padres al trabajo y yo a la escuela", y la imagen muestra cómo la familia sale literalmente disparada como "hombres bala" de un cañón típico de circo; se juega con el uso metafórico de la palabra "disparados" (que significa irse muy rápido), en contraposición al sentido literal que se le da en la imagen (Figura 6). En ¿Todavía nada? se utiliza en varias ocasiones este recurso: cuando el texto dice "no dice ni pío" hay un juego paralelo con la imagen, ya que se trata de un pájaro; y cuando el protagonista dice "estoy hasta el gorro", Luis ha lucido ya hasta cuatro sombreros distintos a lo largo del cuento. 


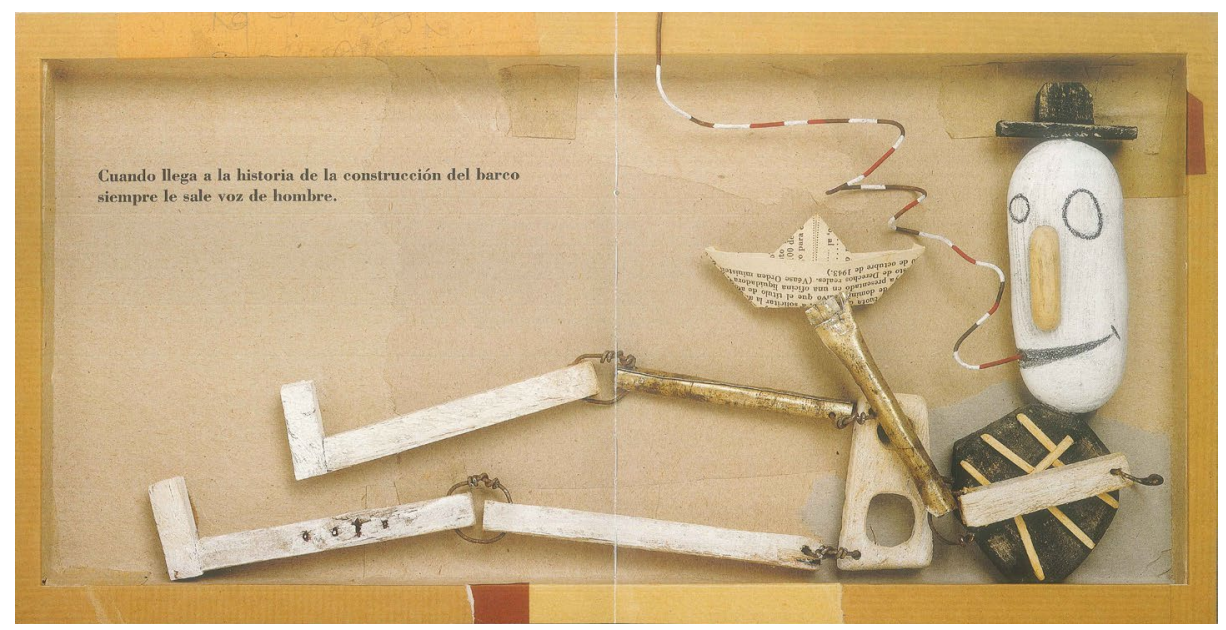

Figura 8. Ilustración de la doble página 22-23, donde se usa el cable como metáfora visual de la voz del abuelo. Fuente: Una casa para el abuelo (Toro y Ferrer, 2007).

En ¿Todavía nada? se juega también con metáforas visuales, pero desvinculadas del texto, para indicar el paso del tiempo: en la doble página 18-19 se muestra una ilustración que se centra en la noche, sin texto, para distender el transcurso del día-noche; y además, a lo largo de todo el cuento se puede ver cómo el protagonista cambia de ropa y complementos para indicar el transcurso de los días al pasar de página.

Por último, en dos de los álbumes destacan los juegos tipográficos con la escala y la composición para llamar la atención sobre el significado de determinadas palabras y acciones. 


\section{Juegos con la realidad y la fantasía}

En todos los álbumes analizados destacan recursos metaficcionales para generar dudas sobre la realidad y la fantasía. Esto se hace de distintas formas:

- La imagen concreta la historia a nivel metaficcional. El final del cuento se concluye con una imagen o varias (normalmente sin el uso de texto) que dará lugar a varias interpretaciones. Por ejemplo, en La familia $C$, en las dos últimas páginas se recupera la realidad mostrando a la familia acudiendo al circo en coche de forma corriente, lo cual hace pensar que todo lo anterior podría ser producto de la fantasía del protagonista.

- El juego con la "Indeterminación" (Lewis, 2001) desde el texto, como se puede ver en ¡No! (donde "¡NO!" es gritado como sonido fuera de campo creando dudas sobre su significado) (Figura 1).

- El uso de la "Ruptura de la frontera narrativa" (Lewis, 2001). Puede ser de varios tipos: con apuntes personales del narrador omnisciente cuyo objetivo es conectar más directamente con el lector (Figura 7); con el texto tachado que se encuentra en El gato de Matilda, haciendo que el narrador, omnisciente en un primer momento, se convierta en protagonista por el poder de contribuir a la narración y destacando así dos momentos distintos de la escena (Figura 3); y desde la imagen, como puede verse en la Figura 9, donde el abuelo, desde su tumba y supuestamente muerto, le señala al espectador la acción que está llevando a cabo su familia (construir la casa encima de su tumba). 


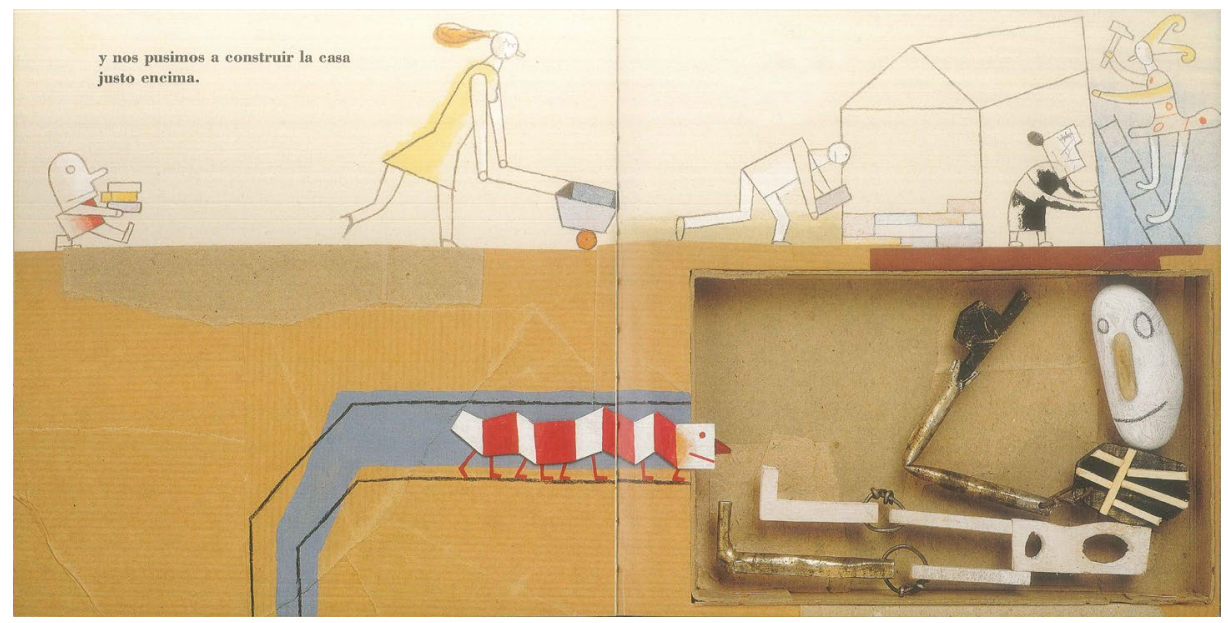

Figura 9. Ilustración de las páginas 14-15, donde el abuelo interpela al lector señalándole a la familia. Fuente: Una casa para el abuelo (Toro y Ferrer, 2007).

\section{Resultados sobre el diseño y la implementación de la actividad didáctica}

La actividad didáctica propuesta tras el análisis de los álbumes de contrapunto se revela como una práctica imprescindible para poder afianzar los conceptos explicados en el aula con anterioridad sobre álbumes de complemento y de contrapunto. El alumno agradece la síntesis que se ofrece en la descripción de la práctica a realizar, donde se muestran las distintas tipologías de álbumes y las posibilidades dentro de éstas, facilitando la comprensión de lo explicado anteriormente.

Tras la realización de la actividad didáctica, destaca una mayor dificultad para reconocer los recursos de contrapunto en los álbumes donde no hay historias contradictorias. En consecuencia, los álbumes iNo! y El gato de Matilda (con historias contradictorias) obtuvieron casi el 100\% de reconocimiento, 
identificándose el "punto de vista" como recurso principal del contrapunto. Sin embargo, los tres álbumes restantes fueron clasificados como álbumes de complemento donde el ilustrador es el máximo responsable en la concreción de la historia. De alguna manera, el alumno fue capaz de reconocer, en la mayoría de los casos, las aportaciones del ilustrador (o de la imagen) en la construcción de la narración, aunque no fuera consciente de la relevancia del contrapunto. Las relaciones de ampliación y complementarias también requieren una descodificación del receptor (Moya-Guijarro y Pinar, 2007, p. 35), aunque exija una menor capacidad cognitiva.

Los recursos de contrapunto que dan lugar a mayor confusión son los de "personajes" y "yuxtaposición". Además, les cuesta reconocer la ambigüedad de las historias tanto desde la imagen como desde el texto, y en su conjunto.

\section{Conclusiones}

Los recursos más recurrentes para generar contrapunto en el álbum ilustrado en general son el "estilo" en primer lugar (5 de 5), el "punto de vista" en segundo (4 de 5), y el "género" en tercer lugar.

En los álbumes de historias contradictorias el recurso de contrapunto fundamental es el "punto de vista"; sin embargo, en los álbumes de historias no contradictorias el recurso fundamental puede variar, y es habitual que se combinen distintos recursos para crear este contrapunto, destacando el "estilo", el "punto de vista" e incluso el "género". Aunque es cierto que los álbumes de historias contradictorias analizados no presentan contrapunto de género, es evidente que también es un recurso utilizado en estos álbumes, como puede verse, por ejemplo, en Lili Takes a Walk (Kitamura, 1991), cuyas ilustraciones se centran en la fantasía y el texto en la realidad para transmitir mensajes contradictorios. 
Cabe destacar también las combinaciones de contrapunto de estilo encontradas que se centran en los binomios objetivo (texto)-romántica (imagen) e ingenuidad (texto)-realista (imagen), advirtiendo que cuando la imagen no es realista, se juega también con el recurso de género, con el binomio realista (texto)-fantástica (imagen); de esta manera, ambos recursos se refuerzan entre sí.

En cuanto al resto de recursos estudiados se observa una tendencia ligada a las tipologías de álbum con contradicción o sin contradicción. En este sentido, los álbumes contradictorios presentan un equilibrio en cuanto al peso narrativo y tienen finales cerrados concretos, puesto que ambos medios son responsables de la concreción de la historia mediante el recurso metaficcional de ironía narrativa. Sin embargo, los álbumes de contrapunto no contradictorios son más variados. Pueden presentar equilibrio en cuanto al peso narrativo o este puede recaer en la imagen. Cuando es la imagen la responsable de concretar la historia, los finales suelen ser abiertos mediante imágenes sugerentes. Los recursos más frecuentes que contribuyen al contrapunto son las metáforas visuales, que suelen tener su origen en el texto.

De todos estos resultados se podrían extraer algunas tipologías que destacan en el álbum de contrapunto:

- El álbum de contrapunto con contradicción. Historias alternativas contradictorias. El peso narrativo se reparte por igual entre la imagen y el texto, y el recurso de contrapunto fundamental es el punto de vista.

- El álbum de contrapunto de concreción. Historias alternativas no contradictorias donde la imagen es la responsable de concretar la narración. El recurso fundamental de contrapunto es el género. 
- El álbum de contrapunto equilibrado. Historias alternativas no contradictorias donde ambos medios son responsables de la construcción de la narración. Los recursos pueden variar, destacando el punto de vista, el estilo o la yuxtaposición.

En cuanto a la actividad didáctica, el álbum de contrapunto con contradicción se revela como el recurso más eficaz en la enseñanza del concepto general de contrapunto y del recurso básico que lo genera, el "punto de vista", (a su vez apoyado por el recurso de "estilo"). En segundo lugar, los álbumes de contrapunto no contradictorios se prestan como ejemplo del recurso de "género", el más destacado y fácilmente reconocible (también en este caso potenciado por el "estilo"). Sería conveniente tener en cuenta estos resultados a la hora de elegir los álbumes que serán parte de las futuras actividades didácticas porque ayudaría a distinguir los recursos de contrapunto y, con ello, las diferencias fundamentales entre álbumes de complemento y contrapunto.

Además, la práctica podría ser mejorada ampliando el número de álbumes a analizar, de esta manera los grupos de trabajo podrían ser más reducidos y posiblemente se aumentaría la eficacia de la actividad en cuanto al reconocimiento de los recursos estudiados. Por último, sería adecuado incluir también álbumes de complemento en el desarrollo de la práctica, lo cual podría contribuir a clarificar las diferencias entre el complemento y el contrapunto.

Con esta investigación se evidencia la complejidad de la relación multimodal en los álbumes de contrapunto, que necesita de una planificación rigurosa por parte del autor o autores. El estudio de este lenguaje visual y el reconocimiento de sus recursos de contrapunto potencia el interés hacia estos libros como medio comunicativo y creativo, a la vez que contribuye a la formación de los actuales estudiantes del Máster de Dibujo que aspiran a convertirse en ilustradores infantiles. 


\section{Referencias}

Altés, M. (2007). ¡No! Thule.

Bajour, C. (2017). La orfebrería del silencio. La construcción de lo no dicho en los libros-álbum. Comunicarte.

Barr, J. (1986). Illustrated Children's Books. The British Library.

Bruno, P. (escritor) y Cabassa, M. (ilustradora) (2010). La familia C. Kalandraka.

Burningham, J. (1999). Time to Get Out of the Bath, Shirley. Red Fox (original publicado en 1978).

Cao, M. (1998). La Retórica visual como análisis posible en la didáctica del arte y de la imagen. Arte, Individuo y Sociedad, (10), 39-62. https://revistas.ucm.es/index.php/ARIS/article/view/ ARIS9898110039A

Colomer, T. (1999). Introducción a la literatura infantil y juvenil. Síntesis.

Colomer, T. (2002). Siete llaves para valorar las historias infantiles. Fundación Germán Sánchez Ruipérez.

Golden, J. M. (1990). The Narrative Symbol in Childhood Literature: Explorations in the Construction of Text. Mouton de Gruyter.

Gravett, E. (2014). El gato de Matilda. Picarona (original publicado en 2012).

Hidalgo-Rodríguez, M. C. (2015). The Interaction between Text and Image in Picture Books. Analysis of Story Books Published in Spain Today. The International Journal of Visual Design, 9(3), 1-14. https://doi.org/10.18848/2325-1581/CGP/v09i03/38741

Hutchins, P. (2015). Rosie's Walk. Little Simon (original publicado en 1968).

Kitamura, S. (1991). Lili Takes a Walk. Dutton Children's Books (original publicado en 1987).

Kress, G., y van Leeuwen, T. (2006). Reading Images. The Grammar of Visual Design. Routledge (original publicado en 1996). 
Kümmerling-Meibauer, B. (1999). Metalinguistic Awareness and the Child's Developing Concept of Irony: The Relationship between Pictures and Text in Ironic. Picture Books. The Lion and the Unicorn, 23(2), 157-183. https://www.academia.edu/4318505/Metalinguistic_ Awareness_and_the_Child_s_Developing_Sense_of_Irony_the_Relationship_between_ Pictures_and_Text_in_Ironic_Picture_Books

Lewis, D. (2001). Reading Contemporary Picturebooks. Picturing text. Routledge; Falmer.

McCallum, R. (1999). Very Advanced Texts: Metafictions and Experimental Works. In P. Hunt (Ed.), Understanding Children's Literature (pp. 115-224). Routledge.

Meek, M. (1988). How Teach What Readers Learn. Thimble Press.

Moss, G. (1990). Metafiction, Illustration and the Poetics of Children's Literature. In P. Hunt, Literature for Children: Contemporary Criticism (pp. 44-66). Routledge.

Moya-Guijarro, A. J. y Pinar, M. J. (2007). La interacción texto/imagen en el cuento ilustrado. Un análisis multimodal. Ocnos: Revista de Estudios sobre Lectura, 3, 21-38. https://doi. org/10.18239/ocnos_2007.03.02

Moya-Guijarro, A. J. (2016). The Role of Semiotic Metaphor in the Verbal-Visual Interplay of Three Children's Picture Books. A Multisemiotic Systemic-Functional Approach. ATLANTIS, Journal of the Spanish Association of Anglo-American Studies, 38(1), 33-52. https://www. atlantisjournal.org/index.php/atlantis/article/view/170

Moya-Guijarro, A. J. (2017). Processing Reality in Picture Books. A Multimodal and Cognitive Study. In S. Neumann et al. (Eds.), Challenging Boundaries in Linguistics. Systemic Functional Perspectives (pp. 429-455). Peter Lang. https://doi.org/10.3726/b10693

Nikolajeva, M., y Scott, C. (2000). The Dynamics of Picturebook Communication. Children's Literature in Education, 31(4), 225-238.

Nikolajeva, M., y Scott, C. (2006). How Picturebooks Work. Routledge (original publicado en 2001).

Nodelman, P. (1990). Words about Pictures. The Narrative Art of Children's Picture Books. University of Georgia Press.

Salisbury, M. (2005). Ilustración de libros infantiles. Cómo crear imágenes para su publicación. Acanto. 
Salisbury, M. y Styles, M. (2012). El arte de ilustrar libros infantiles. Concepto y práctica de la narración visual. Blume.

Schwarcz, J. H. (1982). Ways of the Illustrator: Visual Communication in Children's Literature. American Library Association.

Silva-Díaz, M. C. (2005). Libros que enseñan a leer: álbumes metaficcionales y conocimiento literario (tesis de licenciatura). Universidad Autónoma de Barcelona, España.

Toro, G. (escritor) y Ferrer, I. (ilustrador) (2007). Una casa para el abuelo. Sins Entido (original publicado en 2001).

Turrión-Penales, C. (2012). La ambigüedad de significado en el álbum y su lector implícito. El ejemplo de El Túnel de Browne. Bellaterra Journal of Teaching \& Learning Language \& Literature, 5(1), 60-78. https://www.raco.cat/index.php/Bellaterra/article/view/252385

Van der Linden, S. (2015). Álbum[es]. Ekaré.

Voltz, C. (2003). ¿Todavía nada? Kalandraka (original publicado en 1997).

Whalley J. I., y Chester, T. R. (1988). A History of Children's Book Illustration. John Murray with the Victoria \& Albert.

Zabala, L. (2005). Ironías de la ficción y la metaficción en cine y literatura. UAM.

Cómo citar: Hidalgo, Mª C. (2022). El contrapunto en el álbum ilustrado infantil. Un análisis multimodal para su implementación en la asignatura Ilustración Infantil del Máster de Dibujo (Universidad de Granada). Revista KEPES, 19(25), 427-462. https://doi.org/10.17151/kepes.2022.19.25.15 